\title{
Human capital, cluster formation, and international relocation: The case of the garment industry in Japan, 1968-98
}

\author{
Eiji Yamamura \\ Tokyo Metropolitan University \\ Tetsushi Sonobe \\ Tokyo Metropolitan University \\ Keijiro Otsuka \\ Foundation for Advanced Studies on International Development \\ Corresponding Address: Tetsushi Sonobe \\ Faculty of Economics \\ Tokyo Metropolitan University \\ 1-1 Minami Ohsawa, Hachioji, Tokyo 192-0397, Japan \\ Email: sonobete@bcomp.metro-u.ac.jp \\ Fax: 81-3-426-77-2304
}

May 2002 


\title{
Human capital, cluster formation, and international relocation: The case of the garment industry in Japan, 1968-98
}

\begin{abstract}
This article examines the changing roles of human capital in the process of the formation of industrial clusters, changes in marketing channels, and the relocation of the industrial base to less developed areas and abroad, based on a case study of a garment cluster in postwar Japan. We found among other things that experience as local traders played a major role in the cluster formation. However, formal schooling assumes greater importance in later stages, when direct transactions with large customers replaced transactions with local merchants, and the international relocation of the production base became a major management issue.
\end{abstract}

Keywords: human capital, agglomeration, cluster formation, international relocation JEL Classification: O10, O14, R10, R11 


\section{Introduction}

It has been increasingly and widely recognized that industrial clusters play a significant role in industrial development, not only by economic geographers (e.g., Henderson, 1988; Krugman, 1991) but also by development economists (e.g., Hayami, 1998; World Bank, 2000). ${ }^{1}$ In fact, a large number of case studies report that many industrial clusters exist in developing countries and that they generally grow successfully because they have the capacity to improve the quality of their products and develop new marketing channels in response to changing demands for their products (e.g., Schmitz, 1995; Humphrey and Schmitz, 1996; Schmitz and Nadvi, 1999; Knorringa, 1999; Sonobe, Hu, and Otsuka, 2002). On the other hand, there are econometric studies on industrial locations in the U. S. and Japan using cross-section employment growth data, which commonly find the decentralization of industries away from traditional production centers to other areas (Glaeser et al., 1992; Henderson, et al., 1995; Mano and Otsuka, 2000). ${ }^{2}$ These ostensibly conflicting findings indicate that the growth cycle of an industry entails dynamic processes, in which initial geographical concentration tends to be followed by dispersion.

To our knowledge, however, no empirical study has been undertaken, which inquires into the dynamic processes of cluster formation and the subsequent relocation of the production base to other regions and abroad. ${ }^{3}$ Indeed, in their recent review article on geography and development, Henderson et al. (2001, p. 100) conclude: "One of the areas in which more research is needed ... is the international relocation of industry ...." This is likely due to the lack of detailed long-term statistical data, which would enable us to trace 
the growth cycle of an industrial cluster. Taking advantage of the availability of published production data at the enterprise level in selected years from 1968 to 1998 , this study attempts to analyze the determinants of enterprise performance in a garment cluster in the Bingo area of Japan, which is located in the southeastern part of Hiroshima prefecture. This published data was supplemented by our own survey data on the marketing channels and revenue generation by location of production in relatively recent years, collected from the existing enterprises.

The Bingo area used to be known as a cluster producing kasuri (splashed-pattern cotton cloth) and mompe (traditional women's work trousers with gathers at the ankles made of cotton cloth) since the end of the 19th century. Production was carried out by the wives of farmers at home as a sideline business and products were shipped to large cities by local traders. This area began to be developed as a new garment cluster, producing particularly working clothes used as uniforms at factories and business offices, after World War II when the demand for kasuri and mompe drastically declined. After experiencing rapid growth in the 1960s, enterprises in Bingo shifted the production base primarily to northwestern Kyushu in the 1970s, where the wages of unskilled labor were cheaper by an order of 20 to 30 percent, and almost exclusively to China in the 1990s, where wages were more or less only one-twentieth of the prevailing wages in Bingo. Although the production bases were shifted, the enterprises continued to engage in the design and marketing of garment products in Bingo, as efficient marketing of high-quality and fashionable products is the key to success in the recent garment business. ${ }^{4}$ Introducing 
new products, developing new markets, and choosing new production bases can be regarded as innovations in the sense of Schumpeter (1912), which led to distinct changes in the development of the garment cluster in the Bingo area.

The main purpose of this article is to identify the major characteristics of enterprise managers that were conducive to innovations in various stages of the cluster development in the Bingo area. Specifically, we hypothesize that specific human capital, acquired through work experience by local traders or garment enterprise managers, was an important determinant of the enterprise performance in the early stage of cluster development, whereas general human capital acquired through formal schooling became the critical determinant in the later stages.

The organization of this paper is as follows. After explaining data sources, Section II examines the changing characteristics of enterprises in terms of the size of operation, previous occupation of managers, their schooling, and sales revenues by location of production. Section III postulates hypotheses regarding the changing roles of human capital in the development process of the garment cluster in the Bingo area. Section IV tests our hypotheses statistically by estimating revenue determination functions by both the ordinary least squares and two-stage estimation methods. Finally, Section V summarizes the major findings and discusses the remaining issues.

\section{Changing characteristics of the garment cluster in Bingo}




\section{Data Sources}

The first data source is the Manual of Enterprises in the Textile Industries: Volume for Western Japan (Zenkoku Sen-i Yoran by Shin-yo Kokan Jo (1970-1998)). This source provides data on the number of workers in Bingo (but not in other areas) and total revenue (including revenue generated from production outside Bingo), a brief history of each enterprise, and a biographical sketch of an enterprise manager. The number of enterprises identified from this source, as well as their total and average revenues in real terms, is shown in Table 1.

The Manual, however, sometimes omits important information, such as schooling of enterprise managers. Moreover, it does not exhibit the decomposed revenues generated from production in Bingo, other areas in Japan (primarily in Kyushu), and abroad (primarily in China), and the marketing channels. In order to obtain the supplementary information in 1968, 1982, 1986, 1996, and 1998, we conducted a survey of about 100 existing enterprises from July to September 1999. ${ }^{5}$ In the process of collecting the questionnaires, we conducted informal interviews with about 80 enterprise managers and local traders, in order to grasp the overall patterns of development and the transformation of the garment cluster in the Bingo area. After the repeated visits, we obtained responses from 57 percent of the potential respondents. We believe that our sample enterprises are fairly representative as they include a majority of the active enterprises. We found that complete information has been collected from 36 enterprises in 1968, 43 in 1982, 48 in 1986, and 45 in 1998. Since the sample size is relatively small, we have decided to 
combine our survey data for 1982 and 1986 and for 1996 and 1998 in the regression analyses as discussed in Section IV below. ${ }^{6}$

\section{Growth of the Garment Cluster in Bingo}

The Bingo area has been the largest cluster of working clothes in Japan in the postwar period. According to the Census of Manufacturing (Ministry of International Trade and Industry, various years), the production share of the working clothes in Hiroshima Prefecture, in which the Bingo area has been the single major production center, was 22 percent in 1968, 30 percent in 1986, and 26 percent in 1998, which was second only to that in Okayama Prefecture, where similar garment clusters existed. Although the Bingo area produces other kinds of garments as well, the entire share of the garment products in Hiroshima prefecture was much lower and ranked 5th to 7th among prefectures.

Consistent with the arguments advanced by Marshall (1920, Book 4, Ch.10) regarding the advantages of industrial clusters, spillovers of product, technology, and marketing information among enterprises have been active, subcontracting between garment factories and home-sewers has been common, and labor markets for experienced workers have developed well in the Bingo area. As is shown in Figure 1, the Bingo cluster is geographically small, consisting of Shin-ichi Town and its neighboring areas in Fukuyama and Fuchu Cities. The production share of Shin-ichi Town was 76 percent in 1968 and 63 percent in 1998, whereas the share increased from 16 to 21 percent in Fuchu City and from 7 to 15 percent in Fukuyama City during the same period due primarily to the geographical 
expansion of the Bingo cluster. This geographical proximity was necessary, because face-to-face communication and transactions among the garment enterprises, traders, and subcontractors were the basis to enjoy the localization economies. Needless to say, however, the production area expanded over time as the total value of production increased. According to the production function analysis using city and prefecture data in Japan for 1979 by Nakamura (1985), the garment industry is characterized by significant localization economies.

Table 1 shows that there were 66 garment enterprises in the Bingo area in 1968. Note that a garment enterprise is defined in this study as an enterprise that controls the design and assembly of original garment products and their marketing to wholesalers and retailers. The sample enterprises used home sewers and subcontractors specialized in production, so that the total number of economic units engaged in garment production was much larger. ${ }^{7}$ Subcontracting is also widely used in other garment clusters such as Emilia-Romagna (Brusco, 1982; Biachi and Gualitieri, 1990), Mexico City and its outskirts (Beneria, 1989; Hanson, 1996), and Lima (Visser, 1999). Although detailed statistical evidence is not provided, finer and more flexible specialization and division of labor is practiced in Emilia-Romagna than in Bingo, in order to produce fashionable and high-valued products in the former (Piore and Sabel, 1984).

It appears that many enterprises had entered the garment industry by the end of the 1960s. While the number of enterprises increased only modestly from 1968 to 1977, the total revenue in the Bingo area as a whole, as well as the average revenue of the enterprises, 
increased rapidly during this period. According to our interviews, a modern assembly-line system called the synchronized system, was introduced and widely adopted in this period, in which the fine division of labor was practiced among sewers, replacing the independent production system in which an entire garment was sewn by one sewer. The synchronized system seems to have helped realize the benefits of specialization, thereby increasing the optimum scale of production significantly. This is also the period during which the massive relocation of industries from major metropolitan areas to less urbanized areas took place in Japan (Fujita and Tabuchi, 1997).

The number of enterprises stagnated from 1977 to 1986 and absolutely declined in 1998. Growth in real revenues, both total and average, also became sluggish. Since the garment industry is highly labor-intensive, the Bingo area presumably had lost a comparative advantage in garment production as wage rates in Japan increased dramatically during the high growth period of the 1960s. As will be shown shortly, the production base shifted substantially from Bingo to rural areas of Kyushu and further to China in the 1980s and 1990s, respectively. The main remaining tasks in Bingo were design, marketing, and trial production, as well as the small-scale production of a large variety of fashionable women's clothes. Through such major changes, many garment enterprises in Bingo have been successful in maintaining steadily increasing real sales revenue in the 1980s and 1990s, even though rampant bankruptcy also occurred in the 1990s.

Former Occupation and Schooling of Managers 
According to a historical study of the garment cluster development in the Bingo area by Idehara and Yamana (1997), it was around 1923 when treadle sewing machines were introduced to the Bingo area, when traditional mompe products were produced by farm households. Even before World War II, the demand for such traditional products was stagnant. A major constraint on initiating more promising business, such as modern factory production of garment products, was the lack of market information, which was scarce in such a remote area as Bingo. Mr. Yasutaro Idehara, one of the earliest founders of the most successful garment enterprise in the Bingo area, had been a local trader of kasuri, collecting products from farm households and selling them throughout Japan by himself, before establishing his own garment factory in 1925 (Jichodo, 1981). He believed that accurate urban market information acquired directly by local traders was most valuable for initiating and operating the new garment enterprises in the Bingo area. In short, the development of the garment industry in this area was trader-led, as in the recent development of the same industry in China (Sonobe, Hu, and Otsuka, 2002).

As is shown in Table 2, 41 percent of the garment enterprises in 1968 were operated by former local traders, who generally launched garment businesses before the war. ${ }^{8}$ Their prominence, however, gradually declined. Equally important in 1968 were enterprises established by spin-offs; i.e., former employees of the garment enterprises who resigned during the postwar periods. They were followers, engaged typically in the copied production of their former enterprises. Their enterprise sizes tended to be small, but they accounted for an increasingly large share of the total production in the Bingo area. 
These observations suggest that although former local traders used to have a special advantage in the earlier period, it has gradually been lost over time as spin-offs accumulated marketing experience. Note that the category of "others" in Table 2 includes the former kasuri producers and entrants from other industries.

It is interesting to observe that while the local traders were less educated than the spin-offs in 1968, the managers of the former enterprises became more educated than the latter in 1986 and 1998. ${ }^{9}$ This suggests that former local traders who were uneducated but earned innovators' profits invested heavily in the schooling of their children, who later succeeded their fathers' businesses.

Average schooling levels increased over time, partly because of an increase in the general schooling level in Japan and partly because of the increasing importance of schooling in the management of garment enterprises. Indeed, nearly one-half of the managers were university graduates as of 1998, who studied various subjects including those unrelated directly to the garment business. General schooling, or general human capital, has become important, as a series of major changes in management environments took place requiring new management decisions regarding the upgrading of their products, the establishment of new marketing channels, and the shift of production bases.

\section{Changing Marketing Channels and Production Bases}

When the quality of products improves and their diversity increases, the transaction costs among producers, traders, and consumers tend to increase because of the increasing 
difficulty of checking the quality in advance. In order to convey the quality information, enterprises in this stage seek reputation, goodwill, or brand names (Hayek, 1948, p.97; Marshall, 1920, Book 4, Ch.11). For this purpose, it is often less costly for an enterprise to sell its improved and differentiated products through its own sales agents to department stores, supermarkets, and urban wholesalers, rather than selling them through local traders. According to our interviews, the garment enterprises in the Bingo area gradually increased the proportion of such direct transactions, particularly the use of their own sales agents, as their products were upgraded and differentiated.

Table 3 shows that the ratio of direct transaction was only 24 percent in 1968, but increased appreciably to 60 percent in the 1980 s. $^{10}$ The decade of the 1980 s is precisely the period during which the quality of the garment products was actively improved. Since the former traders must have been adept at marketing, it seems sensible to assume that the enterprises managed by those former traders would have been more successful in securing new direct marketing channels.

Table 3 also shows the changing proportions of revenue generated from production in Bingo, Kyushu, and China (or abroad, strictly speaking). ${ }^{11}$ In 1968, nearly three fourths of the production took place in the Bingo area. The proportion of production in Kyushu increased up to some time in the 1980s and declined significantly in the 1990s. The shift of the production base from Bingo to Kyushu did not entail dramatic changes in production and marketing, as the geographical distance was not large and the wage differential was of an order of only 20 to 30 percent. Basically the same production methods were used as in 
Bingo and products manufactured in Kyushu were shipped to Bingo before being delivered to other domestic areas to take advantage of the existing marketing channels.

Overseas production increased dramatically in the 1990s. Such a shift in the production base from Japan to China required major changes in management, because the capacity to produce sufficiently high-quality products was lacking in China. Consequently, the first task of the Japanese enterprises was to find dependable and potentially capable enterprises in China as subcontractors or partners of joint ventures, while using trading companies as mediators. Secondly, they had to train sewers and management staff in China by sending engineers and other workers from Japan. Thirdly, they had to monitor the quality of the products and ensure the timely delivery of the products to the Japanese markets. Thus, there seems to be no question that in order to be successful in the garment production in China, sufficiently high management capacity was required.

The shift in the production bases from Bingo to Kyushu and further to China can be explained basically by the product cycle hypothesis (Vernon, 1966): Once production methods for differentiated products are standardized, the location of production shifts from a high-wage region to low-wage regions. As will be shown in this article, however, the human capital of enterprise managers played a decisive role in the geographical movement of the production bases.

\section{Role of human capital in cluster development}

In this section, we postulate five testable hypotheses regarding the determinants of 
enterprise performance in the Bingo area based on the observations made in the previous section.

\section{Role of Local Traders}

The production of garment products, particularly low-quality products in the early period, was technically easy and unskilled labor-intensive. The major equipment was sewing machines, which were also used for the production of mompe and, hence, not new to the Bingo area. Rather, the major constraint on the establishment and expansion of the garment business in the early stage was marketing information about the nature of the demand for garment products in distant and large urban markets, such as Osaka and Tokyo. Therefore, a number of the early founders of garment enterprises had been local traders, who were knowledgeable about marketing. This observation suggests the following hypothesis:

Hypothesis 1: Since marketing information was scarce and valuable in the early stage of the cluster formation, it was local traders dealing with traditional products who played the role of entrepreneurs in the garment industry at this stage.

It is interesting to note that local traders of hand-made, low-quality products were major innovators in the formation of the garment cluster in contemporary China (Sonobe, $\mathrm{Hu}$, and Otsuka, 2002) and in the weaving cluster in prewar Japan (Itoh and Tanimoto, 1998). In South India as well, Cathorne (1999) suggests that traders successfully operate 
knit-wear producing enterprises. Therefore, it is clear that the relevance of Hypothesis 1 is not confined to the case of the Bingo area

We test Hypothesis 1 by estimating the reduced-form enterprise sale revenue function, which includes the dummy variable for the local traders as a previous occupation. We expect that the effect of this dummy variable is significant in the 1968 regression, and possibly in the 1977 regression as well, but not for more recent years, because it is likely that market information became less scarce over time in the garment cluster of Bingo.

\section{Increasing Importance of Direct Transactions}

Although solid statistical evidence is difficult to obtain, we heard repeatedly from enterprise managers during our interviews that the inter-enterprise brand competition became intense in the 1980s, when quality upgrading and product differentiation became major issues of enterprise management. In fact, almost all existing enterprises introduced their own brand names by the early 1980s. Using the survey data collected by the Association of Structural Improvement Projects of the Textile Industry (Sen-i Fashion Joho Center, various years), we computed the average unit price of products (i.e., revenue divided by the number of products sold) at the enterprise level in 1982, 1986, 1990, and 1994. The sample enterprises used for price estimates are largely similar to ours. Real average prices in respective years, using the garment product price index (Bank of Japan, 1982-94) as a deflator, were $¥ 1,798, ¥ 1,851, ¥ 2,023$, and $¥ 2,014$ respectively. These data indicate that the quality improved steadily in the 1980s. 
Because local traders were interested in marketing various products supplied by many different producers, those enterprises which had successfully established attractive products tried to develop their own direct marketing channels with supermarkets, department stores, and their own agents, so that their products were not confused with products of other enterprises. Since the introduction of this new marketing method can be considered as an innovation, we postulate the following hypothesis:

Hypothesis 2: As the quality of products improved with brand competition, direct transactions with non-local customers became important in the enterprise performance.

We test this hypothesis by including the direct marketing ratio as an explanatory variable in the enterprise revenue function, while taking into account the endogenous nature of this variable. Since direct marketing was an innovation particularly in the 1980s, we expect that the direct marketing ratio is significant in the pooled 1982/86 regression, but not in the pooled 1996/98 regression.

\section{Relocation of Production Base}

In the 1960s, young unskilled labor was amply supplied to the Bingo area not only from the locality but also from rural areas of Kyushu and Shikoku islands. Such a seemingly "unlimited" supply of cheap labor became no longer available in the 1970s, and so garment enterprises in the Bingo area began to establish branch factories and subsidiaries in the Kyushu area. Since the regional wage differential was not very large, profits from the 
operations in Kyushu were modest. Sooner or later, therefore, the scale of the operations in Kyushu was reduced and, instead, some enterprises began to order production in Southeast Asia and China in the late 1980s. It became evident that production in China was far more profitable in the 1990s because of the much lower wage rates of young workers. In China, both workers' skill and management skill had considerably improved since the mid-1980s, as they accumulated production experience. Thus, most, if not all, garment enterprises in the Bingo area undertook production in China, particularly in the suburbs of Shanghai and Jiangsu province, even though they continued to engage in design and small-scale operation particularly for trial manufacturing in the Bingo area. Since the transfer of the production base to China, and to lesser extent to Kyushu, was profitable, it can be regarded as a major innovation. Thus, we postulate the following hypothesis:

Hypothesis 3: As low-wage labor became unavailable in the cluster area, the transfer of the production base to other areas in Japan and further to abroad became important in the performance of enterprises.

We test this hypothesis by including the ratio of revenue generated by production outside Bingo as an explanatory variable in the 1982/86 revenue function and the similar ratio generated in China in the 1996/98 function, while considering the endogenous nature of these ratio variables. We expect that while the ratios of production in Kyushu and China are both significant, the latter has numerically larger effects than the former, in view of the more massive transfer of the production base to China. 


\section{Increased Schooling Levels of Managers}

While specific marketing knowledge was supposed to be important in the early stage of the cluster development, more general human capital acquired primarily through formal schooling seems to have become a critical determinant of enterprise performances in recent years. There are many examples in which the founders of the garment enterprises, who were uneducated, sent their children to Tokyo for university education, anticipating that schooling would become an important asset in the management of garment enterprises in the future. Although it is well known that most students do not study hard in university in Japan, many of the current managers in Bingo, who are sons of enterprise founders, indicated during our interviews that they have had clear motivation to study seriously in universities. Also, it is highly likely that potentially capable children were selected and sent to universities by their fathers. Based on such observations, we advance the hypothesis that the schooling of managers is an important determinant of major innovations, such as direct marketing and production in Kyushu and China. Thus, we postulate the following hypothesis:

Hypothesis 4: As the quality of products improved and the decisions to relocate the production bases became critically important, the formal schooling of enterprises managers has played an increasingly important role in the expansion of the operation of the enterprises. 
In order to test this hypothesis, we regress the direct marketing ratio and the ratios of revenue generated from production outside Bingo and in China on the schooling of managers, among other things, in the first-stage regression. The predicted values of the direct marketing ratio and the revenue ratios are used in the second-stage regression of total revenue as explanatory variables, in order to test Hypotheses 2 and 3.

So far our analysis has implicitly assumed that the revenue of an enterprise is a good indicator of the enterprise performance. This can be theoretically justified, because the larger production can be explained either by lower marginal and average costs of production and marketing activities, or by higher marginal revenues due to successful product differentiation. In his dynamic model of the evolution of industry with uncertainty of production costs at the individual enterprise level, Jovanovic (1982) rigorously demonstrates that more efficient firms tend to grow larger and have higher survival rates. In order to provide corroborative evidence, we make a probit estimation of the survival function, in which the dependent variable is unity if an enterprise established before 1968 has survived in 1998, while the enterprise revenue in 1968 is a predetermined, independent variable. If the revenue in 1968 has a positive and significant effect in the survival regression, it can be conjectured that the larger scale of production led to higher production efficiency, thereby reducing the probability of bankruptcy. We also assess the impact of the 1968 revenue on the schooling of enterprise managers in 1998, because the managers of larger and more efficient enterprises in the early period might well have invested more heavily in the general human capital of their successors, i.e., their sons. As 
Gertler (2001) cogently puts it, “..ppast events, choice, and decisions limit or constrain today's possibilities and practices" (p. 18).

Our preceding arguments can be summarized in the following hypothesis:

Hypothesis 5: It was the managers of large enterprises in the early stage of cluster formation, who made large investments in the schooling of their successors, namely their sons.

In order to avoid the selection bias arising from the closure of enterprises between 1968 and 1998, we apply Heckman's two-step estimation procedure in which, the enterprise survival function is estimated in the first-step regression and the schooling determination function is estimated in the second-step regression.

\section{Regression analyses}

In this section, we estimate four sets of regression functions. First, we estimate the reduced-form ordinary least squares (OLS) regression of the determinants of enterprise size in terms of the sales revenue, separately for 1968, 1977, 1982/86, and 1996/98. Separate estimations are made in order to test Hypothesis 1 that enterprises managed by former traders were more productive than other types of enterprises in the early stage of the cluster development, and Hypothesis 4 that the schooling of managers has become more important in later years. Then, we employ two-stage estimation methods to identify, firstly, the determinants of direct marketing and its effect on enterprise revenue in 1982/86 and 
1996/98 and, secondly, the determinants of production in Kyushu and China and its effect on enterprise revenue in the same years. Finally, we assess the impacts of enterprise size in 1968 on the probability of survival and the schooling of enterprise managers in 1998.

\section{Determinants of Enterprise Size}

Assuming that the size of an enterprise as measured by the real sale revenue (REV) is a reasonable indicator of enterprise performance, we specified the following reduced-form regression function:

$\ln (\mathrm{REV})_{i}=a_{0}+a_{1} \ln (\text { Years of operation })_{i}+a_{2} \ln (\text { Schooling of manager })_{i}$

$+a_{3}(\text { Trader dummy })_{i}+a_{4}(\text { Spin-off dummy })_{i}+a_{5}$ (Novice dummy $)_{i}+e_{i}$,

where $i$ refers to the $i$-th enterprise and $\mathrm{e}_{i}$ is an error term. The novice dummy is unity if the manager was a novice at producing and selling garments, and it is zero otherwise. The default of the three dummy variables capturing previous occupations, i.e., trader, spin-off, and novice dummies, is the producer of kasuri. Although we expect that the coefficient of the novice dummy is negative, we do not have a clear a priori expectation as to the coefficient of the spin-off dummy. We expect that the effects of the right-hand side variables would significantly change over time. Specifically, we hypothesize that the estimates of $a_{2}$ will become larger over time, whereas $a_{3}$ will become smaller. Similarly, it may be expected that the years of operation will have a stronger effect in the earlier period, when the experience would have been important. Because of these expected changes in 
coefficients, we estimate the above equation separately for the $1968,1977,1982 / 86$, and 1996/98 samples.

The estimation results are shown in Table 4. There are three important findings. First, the coefficients of the local trader dummy are significant only in the 1968 and 1977 regressions but not in the 1982/86 and 1996/98 regressions. These results support Hypothesis 1 that former local traders managed their garment enterprises more efficiently than other types of managers in the early periods of the cluster formation. Second, the coefficients of years of operation are significant in the first three regressions, but both the significance levels and the magnitude of estimated elasticities decline over time. These results may reflect the critical importance of specific experience in garment and related businesses rather than the general ability to collect and decode information for the enterprise management in the earlier years. Lastly, and most importantly, schooling has positive and significant effects on sales revenue in the regressions for the 1982/86 and 1996/98 samples whereas its effect is insignificant in the 1968 and 1977 samples. The estimated coefficients indicate that a one percent increase in schooling increased enterprise revenue by 1.1 percent in 1982/86 and 2.8 percent in 1996/98, in contrast to much lower and insignificant effects in the earlier years. These results imply that schooling has become more important in the later stages of the cluster development, which is consistent with Hypothesis $4 .^{12}$

While it is true that schooling will improve general management ability, a major question is why schooling has become increasingly important in the course of the cluster 
development. An answer is offered by our hypotheses; i.e., major innovations were the expansion of direct marketing with non-local customers and the transfer of the production base to lower-wage areas and countries (Hypotheses 2 and 3), and schooling would facilitate the adoption of these innovations (Hypothesis 4). To test these hypotheses, we estimate a structural equation model in which schooling contributes to enterprise performance through its effects on the proportion of direct marketing and the proportion of revenues generated outside the Bingo area. Since these proportions are censored below zero and above unity, it is practically impossible to endogenize them simultaneously. Thus, we analyze the two types of innovations separately in subsequent analyses.

\section{Determinants of Direct Transaction and its Effect on Enterprise Size}

Presumably, a major reason why schooling is found to be significant in the reduced form regression, particularly for the 1982/86 sample, is that educated managers were more successful in increasing the proportion of direct marketing. Thus, we regress the direct marketing ratio on manager's schooling in the first-stage regression and use the predicted direct marketing ratio, along with manager's schooling, as an explanatory variable in the second-stage regression of the revenue function. Since the direct marketing ratio is censored and ranges from zero to unity, we apply the two-limit tobit estimation method in the first-stage regression. Since this tobit model is heteroscedastic according to a likelihood ratio test conducted in advance, we apply the so-called multiplicative tobit method, in which the variance of error term is assumed to be of the form $\sigma_{i}^{2}=\exp \left(b^{\prime} X_{i}\right)$ 
where $b$ is a vector of unknown parameters and $X_{i}$ is a vector of right-hand side variables. For the sake of identification, we include the working clothes production dummy that is unity for those enterprises whose major products were working clothes, in the first-stage tobit regression. Working clothes can be mass-produced, and the establishment of brand name was more important in the marketing of working clothes than women's clothes and other products, which were essentially niche products produced by small-scale lots.

The estimation results are exhibited in Table 5. It must be emphasized that as far as the 1982-86 regressions are concerned, manager's schooling significantly affects the direct transaction ratio, which, in turn, affects the sales revenue. These results are supportive of Hypotheses 2 and 4. In particular, the positive effect of direct transactions on the enterprise revenue indicates that those enterprises successfully improving products and selling them directly to large customers expanded their business. It is also interesting to observe that the local trader dummy has a positive and significant coefficient in the direct transaction ratio regression, even though it is insignificant in the second-stage revenue regression, which suggests that former traders were more active in developing direct marketing channels. The fact that schooling is also significant in the second-stage regression indicates that it has a positive effect on the enterprise revenue not only through its effect on direct marketing but also through other causal relations. Its elasticity is estimated at 0.69 in Table 5, which is much smaller than the estimated elasticity of 1.10 found in Table 4 for the same period, as the latter is expected to capture both the direct and indirect effects of schooling, whereas the former is supposed to reflect only the direct effect. 
As expected, the working clothes dummy has a positive and highly significant coefficient in the first-stage regression.

Contrasting results are obtained for 1996/98. Manager's schooling has no significant effect on the direct marketing ratio, but it has a positive and highly significant effect on the sales revenue. The former result is expected, because the competition through brand names and marketing channels was no longer critical in the 1990s, while the latter result is reasonable, because schooling was likely to be important in other management decisions. Other variables are generally insignificant.

\section{Determinants of Proportion of Outside Production and Effect on Enterprise Revenue}

The estimation results shown in Table 5 suggest that schooling has a positive effect on the enterprise revenue in 1996/98 through its effects on management other than direct marketing. In our view, another major innovation was the relocation of the production bases to Kyushu and China. Thus, similar to the previous subsection, we endogenize the proportion of revenue generated from production outside Bingo for the 1982-86 regression and the proportion of overseas production for the 1996/98 regression. ${ }^{13}$

Since the proportion of outside production never exceeds unity but is censored below zero and since heteroscedasticity seems to exist, the first-stage regression uses the one-limit, multiplicative tobit estimator. For the purpose of identification, we insert the slacks manufacturer dummy in this first-stage regression. According to our interviews, the design of slacks must be changed quickly with changes in fashion, so that slacks were not 
considered to be suitable for production outside the Bingo area. In contrast, the production of working clothes is highly standardized and, hence, amenable to mass production using the cheap labor force in China.

Table 6 reports the estimation results for the 1982/86 sample and the 1996/98 sample. The most important finding is that the effect of manager's schooling on the proportion of outside production is positive and significant in the first-stage regressions in both samples (see columns 1 and 3), which clearly supports Hypothesis 4. The magnitude of the coefficient is larger in the 1996/98 regression than in the 1982/86 regression, indicating that schooling facilitated more significantly the transfer of the production base to China than to Kyushu. It is also remarkable to find that the effect of outside production on revenue is positive and significant in both periods (columns 2 and 4), but its coefficient is larger in the 1996/98 regression than in the 1982/86 regression. These results are consistent with Hypothesis 3 and suggest that the production in China was highly profitable compared with the domestic production in Kyushu. Note that schooling is not significant in the revenue regressions in both periods, which indicates that schooling had positive effects on enterprise revenues primarily through its effect on the locational choice of production bases.

It may also be worth pointing out that years of operation have a positive and significant effect on the proportion of production in Kyushu but a negative and significant effect on the proportion of production in China. These conflicting results seem to indicate that experienced enterprises tended to be willing to transfer the production base to Kyushu but were hesitant to move to China. This is likely due to the fact that it was the move to 
China, but not to Kyushu, that required major changes in production methods and marketing systems.

\section{Determinants of Long-Term Survival and Schooling of Managers in 1996-98}

There are two major remaining tasks. First, while we have assumed that the size of an enterprise is a good indicator of enterprise performance, this assumption needs to be tested. For this purpose, we will estimate the function explaining the probability that those enterprises existing in 1968 survived in 1998, in which we use the size of the enterprise in 1968 as a predetermined, explanatory variable. If its coefficient is positive and significant, it is likely that the size is positively related with the efficiency of enterprise management. Second, having found the critical and increasing importance of schooling in determining the size of enterprises, it is cogent to ask what factors have affected the schooling of current managers. Since schooling level is a state variable, which is determined by factors affecting the schooling investments made in the past, we have to regress the current schooling on the past variables. Although we do not possess detailed information on potentially important explanatory variables over the past years, it will be of interest to examine the effect of the enterprise size in the early phase of cluster development on the schooling of managers of the surviving enterprises by applying Heckman's estimation procedure. Following the recent arguments on the effects of schooling, work experience, and age on management efficiency advanced by Jovanovic (1982) and Jovanovic and Nyarko (1996), we use the age of managers as an explanatory variable, in addition to years 
of enterprise operation as of 1968, previous occupation dummies, and the size of enterprise in 1968.

At this point, it may be useful to examine the descriptive data on the schooling of enterprise managers. Among 12 distinctively large enterprises existing in 1968 and surviving in 1998, the average schooling of managers as of 1998 was 15.6 years. According to the t-test of the difference in means, this average is significantly larger than the average among smaller enterprises existing both in 1968 and 1998, and than the average of 13.0 years among those enterprises entering after 1968 and surviving in 1998.

The estimates of the enterprise survival function and the schooling determination function are shown in Table 7. In the first and third columns, the dependent variable is unity if the enterprise exists in 1998, and zero otherwise. According to the first column, the revenue in 1968 has a positive and significant effect on the survival of the enterprise. As would be expected, the manager's age has a negative effect because advanced-aged managers had to find capable successors within a short period, which would have been difficult in many cases. The negative effect of the spin-off dummy is reasonable, as such managers are likely to have been inexperienced followers of the garment business.

Because of the strong multi-collinearity between the enterprise revenue and years of operation in 1968, we deleted the revenue in the first-stage regression in the third column. In this specification, the years of operation turned out to have a positive effect.

The fits of the second-stage regressions shown in the second and fourth columns are poor, presumable because of the omission of a number of relevant variables. Nonetheless, 
it is remarkable to find that the revenue in 1968 has a positive and significant effect on the schooling of managers as of 1998. Such a result supports Hypothesis 5.

\section{Concluding remarks}

While it is well known that industrial clusters make important contributions to industrial development, much less is known as to how industrial clusters are formed in the first place. Our analysis indicates that local traders, who possess the relevant marketing knowledge, played a leading role in launching the new business of garment production in a small rural town in Japan. Garment production, particularly the production of low-quality garments, is technically simple and intensive in unskilled labor, so that neither skilled engineers nor large capital is required to initiate a garment enterprise. Therefore, rural areas endowed with a large supply of unskilled labor would have a comparative advantage in this industry. Yet the lack of marketing information, including the nature of urban demands and marketing channels, is a serious constraint on the commencement of a new enterprise. Under such conditions, it is likely that traders play the role of rural entrepreneurs.

A number of recent studies of industrial clusters in developing countries have determined that the upgrading of product quality and exploitation of new marketing channels are essential to sustain the development of industrial clusters in the face of globalization and other changes in market conditions (e.g., Humphrey and Schmitz, 1996; Schmitz and Nadvi, 1999). Our analysis fully concurs. In addition, our analysis found that the formal schooling of enterprise managers is the key factor, which promotes the 
upgrading and development of new markets. This finding is new and, hence, whether and to what extent this is generalizable in other settings needs to be examined by further case studies.

Our analysis found that the geographical relocation of the production base from Bingo to China made a significant contribution to the revenue generation of garment enterprises in the Bingo area. Similar to the formation of the industrial cluster in Bingo several decades earlier, garment production can be initiated successfully in low-wage areas abroad if marketing activities can be carried out effectively by Japanese enterprises. Yet, we failed to analyze the contribution of this geographical relocation to the improvement in technology, management, worker skill, and garment production in China. According to our interviews, the garment enterprises in Bingo found subcontractors and partners of joint ventures in various places in Jiangsu province and the suburbs of Shanghai, suggesting that the relocation has not led to the formation of new industrial clusters in China. It will be worthwhile exploring why this is the case, what determined the locational choice in China, and whether the workers and traders in China initiate garment enterprises based on technology and know-how transferred from Bingo. These are the major remaining issues to be addressed in our future study. 


\section{ENDNOTES}

1. To our knowledge, the definition of industrial cluster is not necessarily clear in the literature. While Porter (1998, p.73) seems to have in mind "cluster of industries connected through vertical and horizontal relationships," Kim et al. (2000) consider industrial cluster as agglomeration of an industry's establishments. In this study, we focus on agglomeration of a single industry, i.e., the garment industry, which enjoys the benefits of localization economies in the sense of Henderson et al. (1995) that arise from the geographic concentration of many firms producing specialized and related products in a small area.

2. Findings of both Glaeser et al. (1992) and Henderson et al. (1995) indicate that growth rates of employment are lower in areas where the initial employment level is larger in the U.S. Mano and Otsuka (2000) observe the same tendency in postwar Japan.

3. A possible exception is Sonobe, $\mathrm{Hu}$, and Otsuka (2001), who analyze the development process of a garment cluster in China in the 1990s.

4. As local producers have raised the quality of products and the speed of production by responding to the demand of traders, traders' core competence tends to be lost (Schmitz and Knorringa, 2000). In fact, local traders in the Bingo area have gradually lost their business over time.

5. Our survey was conducted in collaboration with the Association of the Garment Industry in Hiroshima Prefecture.

6. All the data are available for interested researchers upon request by e-mail at 
otsuka@grips.ac.jp. Names of the sample enterprises, however, cannot be disclosed, as we stated in our questionnaire that the names will never be disclosed.

7. Because of the subcontracting, the number of workers employed by our sample enterprises is a misleading indicator of the size of enterprise operation.

8. According to our own inquiry, out of 46 enterprises founded before the war, 30 were initiated by local traders.

9. Without exception in 1998, managers of these enterprises were successors of founding managers. Also note that the difference in average schooling between the two categories of enterprises is significant only at the 10 percent level.

10. The data in 1997 were unavailable.

11. The Japanese experience is very similar to that of the U.S. where production shifted from New York to the southern U.S. and then to foreign countries including Puerto Rico and East Asian countries. See, for example, Lichtenberg (1960, pp. 103-43).

12. Although not shown here, we ran regressions of the average growth rate, between 1968 and 77, between 1977 and 86, and between 1986 and 98, on the same set of explanatory variables as that in Table 4 . The results were qualitatively the same as Table 4 and consistent with Hypotheses 1 and 4.

13. We lumped together production in Kyushu and abroad for 1982/86, because of its overwhelming importance. On the other hand, we did not consider the production in Kyushu as a part of outside production for 1996/98. This specification presumes that production in Kyushu was no longer an innovative activity at the end of the 1990s, 
which would be reasonable.

\section{AKNOWLEDGEMENTS}

We are heavily indebted to Seizo Idehara and Hachiro Sato, who were respectively the chairman and the executive director of the Association of the Garment Industry in Hiroshima Prefecture, for data collection and guidance about the development of the garment cluster in the Bingo area. We are also grateful to Richard Arnott and anonymous reviewers of this journal for helpful comments and suggestions, and Paul Kandasamy for his editorial assistance. 


\section{REFERENCES}

Bank of Japan (1970-1999) Bukka Shisu Nenpo (Annual Report of Price Indexes). Bank of Japan, Statistical Bureau.

Beneria, L. (1989) Subcontracting and Employment Dynamics in Mexico City. In A. Portes, M, Castells, and L.A. Benton (eds) The Informal Economy: Studies in Advanced and Less Developed Countries. Baltimore: Johns Hopkins University Press.

Bianchi, P., Gualtieri, G. (1990) Emilia-Romagna and its Industrial Districts: The Evolution of a Model. In R. Leonardi and R.Y. Nanetti (eds) The Regions and European Integration: The Case of Emilia-Romagna. London: Pinter Publishers.

Brusco, S. (1982) The Emilian Model: Productive Decentralization and Social Integration. Cambridge Journal of Economics, 6: 167-184.

Cathorne, P.M. (1999) Of Networks and Markets: The Rise of a South Indian Town, The Example of Tiruppur's Cotton Knitwear Industry. $\quad$ World Development, 23: 43-56.

Fujita, M., Tabuchi, T. (1997) Regional Growth in Post War Japan. Regional Science and Urban Economics, 27: 643-670.

Gertler, M.S. (2001) Best Practice? Geography, Learning and the Institutional Limits to Strong Convergence. Journal of Economic Geography, 1: 5-26.

Glaeser, E.L., Kallal, H.K., Sheinkman, J.A., Shleifer, A. (1992) Growth in Cities. Journal of Political Economy, 100: 1126-1152.

Hanson, G.H. (1996) Agglomeration, Dispersion, and the Pioneer Firm. Journal of Urban 
Economics, 39: 255-281.

Hayami, Y. (ed.) (1998) Toward the Rural-Based Development of Commerce and Industry: Selected Experiences from East Asia. Washington, DC: World Bank Economic Development Institute.

Hayek, F.A. (1949) The Meaning of Competition. in Individualism and Economic Order, London: Routledge \& Kegan Paul.

Henderson, J.V. (1988) Urban Development: Theory, Fact, and Illusion. New York: Oxford University Press.

Henderson, J.V., Kuncoro, A., Turner, M. (1995) Industrial Development in Cities. Journal of Political Economy, 103: 1067-1090.

Henderson, J.V., Shalizi,Z., Venables, A.J. (2001) Geography and development. Journal of Economic Geography, 1: 81-105.

Humphrey, J., Schmitz, H. (1996) The Triple C Approach to Local Industrial Policy. World Development. 24: 1859-1877.

Idehara, J., Yamana, H. (1997) Bingo’s Splashed-Pattern Cloth (Bingo Gasuri). Shinichi Town in Hiroshima Prefecture, Shinichi-Choritsu Rekishi-Minzoku Shiryokan.

Jichodo (1981) Progress of Jichodo in the Past 60 Years (Jichodo 60 Nen no Ayumi). Shinichi Town in Hiroshima Prefecture, Jichodo.

Jovanovic, B. (1982) Selection and the Evolution of Industry. Econometrica, 50: 649-670. Jovanovic, B., Nyarko, Y. (1996) Learning by Doing and the Choice of Technology. Econometrica, 64: 1299-1310. 
Knorringa, P. (1999) Agra: An Old Cluster Facing the New Competition. World Development, 27: $1587-1604$.

Krugman, P. (1991) Geography and Trade. Cambridge, MA: Massachusetts Institute of Technology Press.

Lichtenberg, R. M. (1960) One-Tenth of Nation: National Forces in the Economic Growth of the New York Region. Cambridge, MA: Harvard University Press.

Mano, Y., Otsuka, K. (2000) Agglomeration Economies and Concentration of Industries: A case study of Manufacturing Sectors in Post-War Japan. Journal of Japanese and International Economies, 14: 189-203.

Marshall, A. (1920) Principles of Economics: An Introductory Volume. New York: Macmillan.

Ministry of International Trade and Industry (various years) Census of Manufacturing.

Nakamura, R. (1985) Agglomeration Economies in Urban Manufacturing Industries. A Case of Japanese Cities. Journal of Urban Economics, 17: 108-124.

Piore, M.J., Sabel, C.F. (1984) The Second Industrial Divide: Possibilities for Prosperity. New York: Basic Books.

Schmitz, H. (1995) Collective Efficiency: Growth Path for Small-Scale Industry. Journal of Development Studies, 31: 529-566

Schmitz, H., Nadvi, K. (1999) Clustering and Industrialization. World Development, 27: 1503-1514.

Schmitz, H., Knorringa, P. (2000) Learning from Global Buyers. Journal of Development Studies, 
37: 177-205.

Schumpeter, J, A. (1912) The Theory of Economic Development. New York: Oxford University Press.

Sen-i Fashion Joho Center $(1982,1986,1990,1994)$ A Survey of Domestic and Overseas Garment Production for Domestic Markets (Iryohin Kokunaimuke no Kokunai Seisan-Kaigai Seisan Jittai Chosa). Sen-i Sangyo Kozo Kaizen Jigyo Kyokai.

Shin-yo Kokan Jo (1970-1998) Manual of Enterprises in the Textile Industries: Volume for Western Japan (Zenkoku Sen-i Kigyo Yoran Nishi Nihon Ban). Tokyo: Shin-yo Kokan Jo.

Sonobe, T., Hu, D., Otsuka, K. (2002) Dynamic Process of Formation and the Role of Traders: A Case Study of a Garment Town in China. Journal of Development Studies, forthcoming.

Vernon, R. (1966) International Investment and International Trade in the Product Cycle. Quarterly Journal of Economics, 80: 197-207.

Visser, E-J. (1999) A Comparison of Clustered and Dispersed Firms in the Small-Scale Clothing Industry of Lima. World Development, 27: 1553-1570.

World Bank (2000) World Development Report 2000. New York: Oxford University Press. 
Table 1. Changes in number of enterprises, total sales revenue, and average sales revenue of enterprises, 1968-1998

\begin{tabular}{cccc}
\hline Number of enterprises & $\begin{array}{c}\text { Total sales revenue in } \\
\text { Bingo } \\
\text { (billion Yen) }\end{array}$ & $\begin{array}{c}\text { Average sales revenue } \\
\text { per enterprise } \\
\text { (million Yen) }\end{array}$ \\
\hline 1968 & 66 & 15.9 & 236 \\
1977 & 86 & 84.0 & 977 \\
1986 & 89 & 148.0 & 1,660 \\
1998 & 75 & 173.0 & 2,303 \\
\hline
\end{tabular}

Note: Both total sale revenue and average sales revenue are deflated by the price index of garment products, which is obtained from Bank of Japan (1970-1999).

Source: Shin-yo Kokan Jo (1970-1998). 
Table 2. Proportions of enterprise managers by former occupation and formal schooling, 1968-1998

\begin{tabular}{cccccccc} 
& \multicolumn{3}{c}{ Former Occupation $(\%)$} & & \multicolumn{3}{c}{ Average Schooling (years) } \\
\cline { 2 - 3 } \cline { 6 - 8 } year & $\begin{array}{c}\text { Local } \\
\text { traders }\end{array}$ & Spin-offs & Others & & $\begin{array}{c}\text { Local } \\
\text { traders }\end{array}$ & Spin-offs & Others \\
\hline 1968 & 40.9 & 42.4 & 16.7 & & 10.2 & 11.9 & 9.7 \\
1977 & 32.5 & 53.4 & 14.1 & & 11.5 & 12.0 & 9.9 \\
1986 & 31.4 & 56.1 & 12.5 & & 13.1 & 12.1 & 12.0 \\
1998 & 34.6 & 52.0 & 13.4 & & 14.1 & 13.1 & 13.6 \\
\hline
\end{tabular}

Source: Shin-yo Kokan Jo (1970-98). 
Table 3. Proportions of direct transactions and sales revenue by location (\%), 1968-1998

\begin{tabular}{|c|c|c|c|c|}
\hline \multirow[b]{2}{*}{ year } & \multirow{2}{*}{$\begin{array}{l}\text { Direct transaction } \\
\text { ratio }^{\text {a }}\end{array}$} & \multicolumn{3}{|c|}{ Revenue generated by location } \\
\hline & & Bingo & Kyushu & Abroad \\
\hline 1968 & 24 & 74 & 25 & 1 \\
\hline $1982 \& 86$ & 60 & 51 & 39 & 10 \\
\hline $1996 \& 98$ & 74 & 29 & 23 & 48 \\
\hline
\end{tabular}

Notes: The data for 1977 are unavailable.

a. Proportion of direct transactions with non-local customers, as opposed to transactions through local traders.

Source: The authors' survey. 
Table 4. Determinants of enterprise revenue (Reduced-form OLS estimation)

\begin{tabular}{|c|c|c|c|c|}
\hline & $\begin{array}{l}\ln \text { (Revenue) } \\
\text { in } 1968\end{array}$ & $\begin{array}{l}\ln \text { (Revenue) } \\
\text { in } 1977\end{array}$ & $\begin{array}{c}\text { In (Revenue) } \\
\text { in 1982/86 }\end{array}$ & $\begin{array}{c}\text { In (Revenue) } \\
\text { in } 1996 / 98\end{array}$ \\
\hline $\ln$ (Years of operation) & $\begin{array}{c}0.63 * * \\
(4.85)\end{array}$ & $\begin{array}{c}0.65 * * \\
(3.14)\end{array}$ & $\begin{array}{c}0.49 * * \\
(2.66)\end{array}$ & $\begin{array}{c}0.30 \\
(1.19)\end{array}$ \\
\hline $\ln$ (Manager's schooling) & $\begin{array}{c}0.45 \\
(1.50)\end{array}$ & $\begin{array}{c}0.42 \\
(1.24)\end{array}$ & $\begin{array}{l}1.10 * * \\
(3.69)\end{array}$ & $\begin{array}{l}2.80 * * \\
(3.69)\end{array}$ \\
\hline Local trader dummy & $\begin{array}{l}0.52^{*} \\
(1.71)\end{array}$ & $\begin{array}{l}0.60^{*} \\
(1.72)\end{array}$ & $\begin{array}{l}-0.22 \\
(-0.59)\end{array}$ & $\begin{array}{c}0.50 \\
(1.11)\end{array}$ \\
\hline Spin-off dummy & $\begin{array}{c}0.43 \\
(1.04)\end{array}$ & $\begin{array}{c}0.61 \\
(1.36)\end{array}$ & $\begin{array}{c}0.00 \\
(0.02)\end{array}$ & $\begin{array}{c}0.65 \\
(1.46)\end{array}$ \\
\hline Novice dummy & $\begin{array}{l}-0.26 \\
(-0.67)\end{array}$ & $\begin{array}{c}-0.66 \\
(-1.49)\end{array}$ & $\begin{array}{l}-0.68 \\
(-1.27)\end{array}$ & $\begin{array}{c}-0.84 \\
(-1.54)\end{array}$ \\
\hline Year dummy ${ }^{\text {a }}$ & & & $\begin{array}{c}0.08 \\
(0.42)\end{array}$ & $\begin{array}{c}0.18 \\
(0.78)\end{array}$ \\
\hline Constant & $\begin{array}{l}8.72 * * \\
(10.5) \\
\end{array}$ & $\begin{array}{l}9.86^{* *} \\
(9.61) \\
\end{array}$ & $\begin{array}{l}9.69 * * \\
(9.07) \\
\end{array}$ & $\begin{array}{l}5.03 * * \\
(2.37) \\
\end{array}$ \\
\hline Adj. $R^{2}$ & 0.41 & 0.20 & 0.19 & 0.17 \\
\hline Number of observations & 47 & 61 & 79 & 93 \\
\hline
\end{tabular}

Notes: Numbers in parentheses are t-values.

a. Year dummy is equal to unity if year is 1982 in the regression using the 1982/86 sample and if year is 1996 in the regression using the 1996/98 sample, and it is zero otherwise.

$*$ and $* *$ indicate significance at the 5 and $1 \%$ levels, respectively (one-side test).

Source: Shin-yo Kokan Jo (1970-98). 
Table 5. Determinants of direct transaction and enterprise revenue (Two-stage estimation)

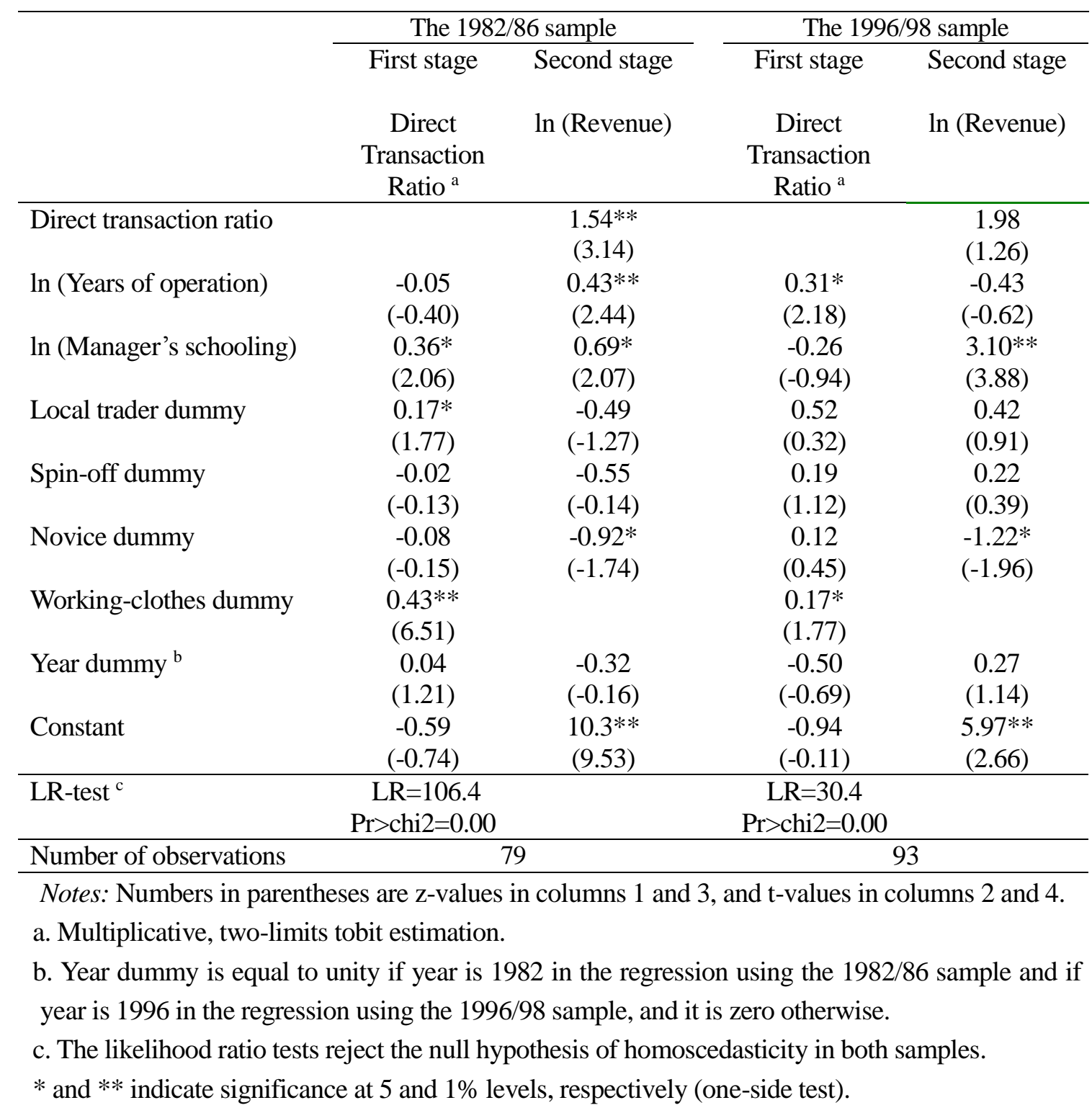


Table 6. Determinants of location and enterprise revenue (Two-stage estimation)

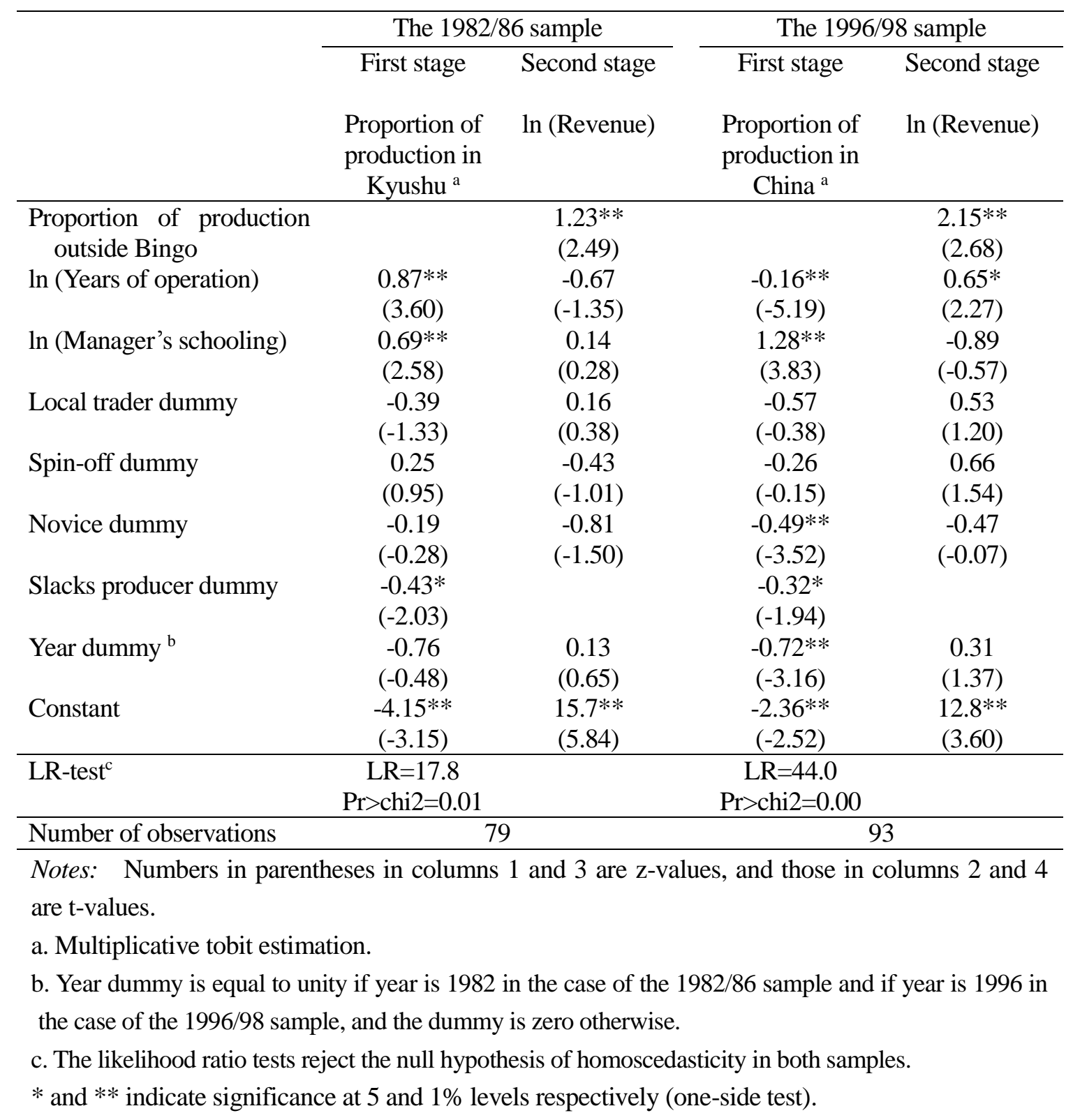


Table 7. Determinants of manager's schooling of surviving enterprise (Two-step estimation)

\begin{tabular}{|c|c|c|c|c|}
\hline & \multicolumn{2}{|c|}{ Specification 1} & \multicolumn{2}{|c|}{ Specification 2} \\
\hline & First step & Second step & First step & Second step \\
\hline & $\begin{array}{l}\text { Survival } \\
\text { in } 1998^{\text {a }}\end{array}$ & $\begin{array}{l}\text { ln (Manager's } \\
\text { schooling) } \\
\text { in } 1998\end{array}$ & $\begin{array}{l}\text { Survival } \\
\text { in } 1998^{\text {a }}\end{array}$ & $\begin{array}{c}\text { In (Manager's } \\
\text { schooling) } \\
\text { in } 1998\end{array}$ \\
\hline ln (Manager's age in 1968) & $\begin{array}{l}-3.12 * * \\
(-2.71)\end{array}$ & & $\begin{array}{l}-2.23 * * \\
(-2.35)\end{array}$ & \\
\hline ln (Revenue in 1968) & $\begin{array}{c}0.83 * * \\
(3.17)\end{array}$ & $\begin{array}{l}0.07^{*} \\
(1.89)\end{array}$ & & $\begin{array}{l}0.06^{*} \\
(2.11)\end{array}$ \\
\hline ln (Manager's age in 1998) & & $\begin{array}{c}-0.09 \\
(-0.77)\end{array}$ & & $\begin{array}{c}-0.07 \\
(-0.64)\end{array}$ \\
\hline ln (Years of operation) & $\begin{array}{c}0.27 \\
(1.20)\end{array}$ & & $\begin{array}{c}0.48 * * \\
(2.32)\end{array}$ & \\
\hline Local trader dummy & $\begin{array}{c}-0.86 \\
(-1.06)\end{array}$ & $\begin{array}{c}-0.02 \\
(-0.35)\end{array}$ & $\begin{array}{c}-0.18 \\
(-0.29)\end{array}$ & $\begin{array}{c}-0.02 \\
(-0.28)\end{array}$ \\
\hline Spin-off dummy & $\begin{array}{l}-1.45^{*} \\
(-1.69)\end{array}$ & $\begin{array}{c}-0.02 \\
(-0.26)\end{array}$ & $\begin{array}{c}-0.84 \\
(-1.26)\end{array}$ & $\begin{array}{c}-0.03 \\
(-0.32)\end{array}$ \\
\hline Novice dummy & $\begin{array}{c}-0.67 \\
(-1.24)\end{array}$ & $\begin{array}{c}-0.10 \\
(-0.98)\end{array}$ & $\begin{array}{c}-0.77 \\
(-1.57)\end{array}$ & $\begin{array}{c}-0.09 \\
(-0.86)\end{array}$ \\
\hline Constant & $\begin{array}{c}2.92 \\
(0.71)\end{array}$ & $\begin{array}{c}2.04 * * \\
(2.57)\end{array}$ & $\begin{array}{l}7.98^{*} \\
(2.19) \\
\end{array}$ & $\begin{array}{c}2.18 * * \\
(2.96) \\
\end{array}$ \\
\hline Inverse Mills’ ratio & & 0.06 & 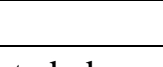 & 0.04 \\
\hline
\end{tabular}

Notes: The number of observations is 64 , and the number of truncated observations is 33 in both sets of regressions. Numbers in parentheses in the first-step regressions are z-values, and those in the second-step regressions are t-value.

a. Probit estimation.

$*$ and $* *$ are significance at 5 and $1 \%$ levels respectively (one-side test). 


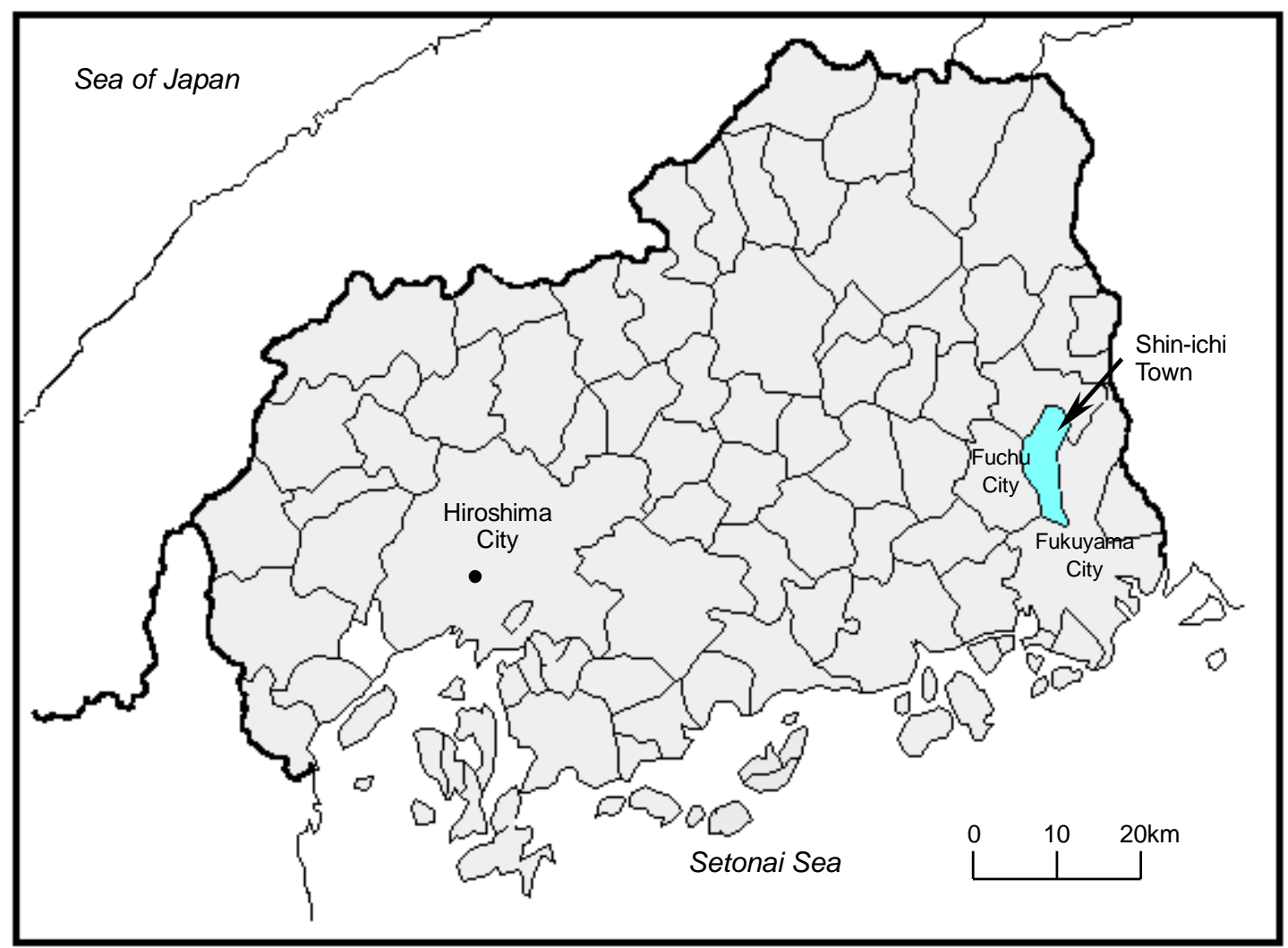

Figure 1. Location of the Bingo Garment Cluster in Hiroshima Prefecture 